\title{
Modified Pectins for Colon-Specific Drug Delivery
}

\author{
Aneesh Muvva, Indhu Annie Chacko, Vivek Ghate, Shaila Angela Lewis*
}

Department of Pharmaceutics, Manipal College of Pharmaceutical Sciences, Manipal Academy of Higher Education (MAHE), Manipal, Karnataka, INDIA.

\begin{abstract}
Treatment of local diseases such as ulcerative colitis, Crohn's disease, irritable bowel syndrome and colonic cancer by targeting drug to the colon is a viable approach. Due to gastric degradation of drugs, proteins and peptides, only minimum amount of drug gets absorbed when administered orally and shows little therapeutic activity. Hence the strategy of delivering drugs to colon known as colon targeted drug delivery evolved. Pectin a naturally occurring biodegradable polysaccharide has gained importance as a carrier for colon-specific delivery attributed to swelling nature as well as the ability to resist gastric degradation. This review describes the chemistry of pectin, mechanism of action and various novel modified pectin formulations aimed at targeting the colon.
\end{abstract}

Key words: Colon targeting, Intestinal microflora, Modified pectin forms, Gelling property, biodegradable polysaccharide, Drug delivery.

\section{INTRODUCTION}

\section{Overview of colon and diseases}

The distal part of the Gastrointestinal Tract (GIT), called the colon is a major site for the absorption of aqueous media and the water-soluble constituents mainly the electrolytes. The colon extending to several centimeters in length when stretched from end to end is characteristically divided into the cecum, ascending, descending and the sigmoid units and the rectum. ${ }^{1}$ The epithelial cells that make up the colon have an extreme ability to secrete mucin culminating in a protective covering called the mucus layer. Mucus layer is responsible for protecting the underlying tissues from harsher conditions. The $\mathrm{pH}$ of the colonic contents range from almost neutral to slightly alkaline and colon as a whole is recognized for its programmed contractions termed as peristaltic movements. ${ }^{1,2}$ The constant contraction and involuntary movements of the colon not only plays an important role in the absorption of water and essential nutrients, but also is a significant factor governing the absorption of drugs that are administered orally. Particularly, in conditions of diseases affecting the colon, it is of extreme importance that the drug is allowed to be exposed to the region of interest for a longer time, before being ultimately expelled from the body.

\section{Microflora of the colon}

Another factor that usually is well-established in the context of colon includes the descriptions of the microflora residing within it. ${ }^{1,2}$ With more than 300 species of bacteria inhabiting the colon, aids well in the breakdown and absorption of the complex carbohydrates, proteins, bile acids and other substances vital to the human body. A notable influence of the enzymatic reactions brought about by the colonic bacteria is seen during the breakdown of polysaccharides. ${ }^{1,2}$ Thus it is of great interest for formulation scientists to use polysaccharides in delivering the drugs to the colonic regions taking into consideration the bacterial metabolism, in turn aiding the release of the entrapped drug.

\section{Polysaccharide-based approach}

Natural polysaccharides originate from plants, microbes or animals and are split
Submission Date: 25-07-2019; Revision Date: 06-02-2020; Accepted Date: 12-03-2020

DOI: 10.5530/ijper.54.2s.57 Correspondence: Dr. Shaila Angela Lewis Department of Pharmaceutics, Manipal College of Pharmaceutical Sciences, Manipal Academy of Higher Education (MAHE), Manipal576104, Karnataka, INDIA. Phone: +919449283222

E-mail: s.lewis@manipal.edu

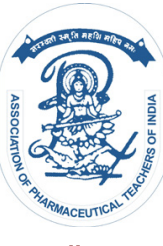

www.ijper.org 
into simple saccharides by colonic microflora. These polysaccharide-based drug delivery systems protect bioactivity against the harmful conditions of gastric fluid. Bioactive molecules that are entrapped in the polysaccharide networks undergo hydrolysis of the glycosidic linkage on arrival in the colon, which in turn triggers drug delivery resulting in therapeutic action. The saccharolytic species responsible for biodegradation of polysaccharides include Bacteroides and Bifidobacterium. ${ }^{1}$ Colonic regions contain a large number of anaerobic micro-organisms secreting numerous enzymes ${ }^{2,3}$ which metabolize polysaccharides with the drug resulting in polysaccharide degradation followed by the release of drug in the colonic region. The polysaccharides explored for colon targeted drug delivery are chitosan, dextran, pectin, ethyl cellulose and hyaluronic acid. All these polymers are biodegradable and embedded with the drug by various modifications. When administered orally they reach the colon region and release the drug by enzymatic degradation of polysaccharides.

The present review mainly focuses on modified Pectin formulations reported in literature to treat various pathological conditions associated with the colon including inflammatory bowel disease and cancer.

\section{Pectin and its composition}

Pectins are structural polysaccharides of the plant cell wall, consisting mainly of galacturonic acid units, which differ in composition, structure and molecular weight. They are often linked to other cell wall components such as cellulose, hemicellulose and lignin. ${ }^{4}$ In addition to the food industry, pectin has immense potential as a carrier in controlled drug release and, in many other areas like pharmaceuticals and medicine. ${ }^{5}$ The use of pectin has been reported for instance, in nasal, ocular and oral drug delivery $^{6}$ as well as wound healing. ${ }^{7}$

\section{Chemistry of pectin}

The three main domains of pectin molecule are the: $\alpha$-(1 - 4)-linked, irregular, linear homo - galacturonic backbone (HG), with 2 forms of highly - branched regions called the RG - I and the RG - II, which are heterogeneous polysaccharides. Arabinose and galactose side chains replace RG - I. RG - II consists of a well preserved HG backbone, including some rare sugars: 2-O methyl xylose, 2-O methylfucose, apiosis, aceric acid and 2-keto-3-deoxide - d-mano - octulosonic acid and 3-deoxide - d - lyxo-2-heptulosaric acid. ${ }^{8}$ Most of the natural pectins having carboxyl groups exist as ester form.

\section{Sources of pectin}

Pectin is present in almost every plant, but the majority of pectin's are produced commercially from citrus fruits like orange, lemons, grapefruit and apples. ${ }^{9}$

\section{Applications of pectin}

Pectins are reported to have numerous applications. ${ }^{10}$ They include notable prebiotic effect, effect on insulin, in cancer prevention (prostate, colon, breast, pancreatic), anti-proliferative effect and biomedical applications (drug delivery, tissue engineering, wound healing and wound dressing material, and gene delivery).

\section{Pectin for drug delivery}

Though a wide range of polysaccharides such as chondroitin sulfate, chitosan, dextran, amylase and inulin are available for colon specific delivery, pectin is most sought and tops the list. Pectin has proven best suited for the supply of colonic medicines because it forms macromolecular additives in the upper portion of GIT and colonized by colonic engraving. ${ }^{11}$ Pectin is also considered a suitable mode of delivery for the drug because of properties such as biocompatibility, mucoadhesiveness, safety, inertness and ability to gel in acidic environments. ${ }^{11,12}$ However, natural pectin is highly soluble in acidic media and leads to the premature release of the drug.

\section{Modification of pectins}

Inherently pectin is water soluble and tend to release the drug prematurely within the initial regions of the GIT, well-before reaching the colon. In order to control the unintended release of the drug, it was reported to form a thick coating of pectin onto the drug core. ${ }^{13}$ Realizing the drawbacks of thick coating, researchers opted for preparing the derivative of pectin that was stable at the various $\mathrm{pH}$ conditions but were able to be metabolized by the colonic bacteria. ${ }^{14}$ This concept has acquired great relevance in controlled release of drugs directed to the colon, to treat diseases such as colon cancer, irritable bowel disease and Crohn's disease, among others. Diverse studies have been reported in the last decade regarding the use of pectin for drug release. ${ }^{15}$

\section{Mechanism of drug release}

Pectin a hydrophilic polysaccharide, due to its ability to gel, can alter drug release. The polysaccharide is known to be gastric- and intestinal resistant but is metabolized in the colon by anaerobic bacteria. ${ }^{14}$ Colonic drug metabolism may lead to the formation 
of pharmacologically active metabolites for the colonspecific drug delivery system. ${ }^{16}$ An overview of the drug release and absorption, due to the activity of the resident microflora has been shown in Figure 1.

\section{Various formulations of pectins targeting the colon}

Formulations include single unit dosage forms, multiparticulate dosage forms and pectin combined with other polysaccharides. A comprehensive detail on various types of pectin-based formulations have been provided in Table 1 and Table 2. The pectin based systems as microparticles and nanoparticles have been provided in Table 3 and Table 4, respectively.

\section{Single- and multi-unit dosage forms}

\section{Matrix tablets}

Due to the high degree of fragmentation, elasticity and plastic deformation, the compatibility of pectin is poor. ${ }^{17}$ Hence, the addition of plastic excipients such as EMDEX was employed. ${ }^{18}$ Pectin matrix studies on reducing drug release rate in an environment mimicking the gastric and small intestinal environment from the

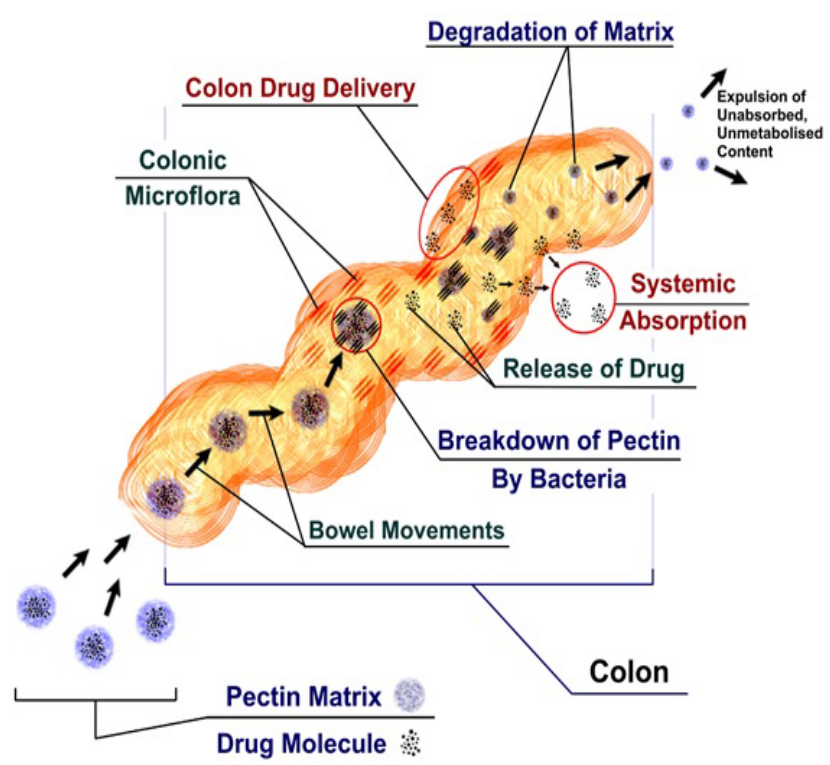

Figure 1: The drug delivery either to the systemic circulation or local colonic tissue using pectin as matrix proceeds with the metabolism of pectin by the resident microflora, thereby slowly eroding the matrix to release the drug. The time of exposure to these microorganisms is limited due to the strong contractions and bowel movements making it a challenge to retain the drug delivery systems at the site of release and action.

\begin{tabular}{|c|c|c|c|}
\hline Dosage form & Drug model used & Preparation Method & References \\
\hline Amidated-pectin Eudragit Matrix tablets & Ropivacaine & Direct compression method & 17 \\
\hline Pectin-HPMC compression coated & Calcium sennoside & Wet granulation & 39 \\
\hline Enteric coated Pectin Matrix tablets & Theophylline & Direct compression & 18 \\
\hline Pectin-Ethyl cellulose Film-coated tablets & Paracetamol & $\begin{array}{l}\text { Direct compression followed by } \\
\text { fluid bed spray coating }\end{array}$ & 30 \\
\hline Calcium-Pectinate compressed tablets & Indomethacin & Direct compression & 40 \\
\hline Calcium-Pectinate capsules & 5-Fluorouracil & $\begin{array}{l}\text { 5-Fu granules prepared by wet } \\
\text { granulation and loaded into the } \\
\text { capsule }\end{array}$ & 14 \\
\hline Pectin-Chitosan compression coated mini tablets & Indomethacin, Paracetamol & $\begin{array}{l}\text { Direct compression followed by } \\
\text { coating }\end{array}$ & 33 \\
\hline $\begin{array}{c}\text { Modified Pulsincap (pellets were incorporated into } \\
\text { capsule shell) } \\
\text { Eudragit coated pectin pellets }\end{array}$ & $\begin{array}{l}\text { Metronidazole } \\
\text { Aceclofenac }\end{array}$ & $\begin{array}{l}\text { By extrusion spheronization method } \\
\text { Twin screw extruder/FB coater }\end{array}$ & 41 \\
\hline Pectin-HPMC-Calcium matrix tablet & Indomethacin & Wet granulation & 42 \\
\hline Amidated pectin-Zinc tablet & Ketoprofen & $\begin{array}{l}\text { Ionotropic gelation of amidated } \\
\text { pectin with zinc ions resulting } \\
\text { inmicroparticles followed by } \\
\text { compression of microparticles }\end{array}$ & 23 \\
\hline Eudragit $L$ coated Calcium pectinate tablet & Samarium oxide & & 43 \\
\hline Pectin-HPMC compression coated tablets & 5-Aminosalicylic acid & $\begin{array}{l}\text { Wet granulation followed by } \\
\text { compression coating }\end{array}$ & 34 \\
\hline Eudragit coated pectin tablets & Levetiracetam & $\begin{array}{l}\text { Wet granulation followed by coating } \\
\text { with Eudragit polymer by using } \\
\text { Fluidized bed coater }\end{array}$ & 44 \\
\hline Chitosan-Pectin polyelectrolyte complex tablets & Vancomycin & $\begin{array}{l}\text { Direct compression of } \\
\text { microspheres }\end{array}$ & 45 \\
\hline
\end{tabular}




\begin{tabular}{|c|c|c|c|}
\hline Dosage form & Drug model used & Preparation Method & References \\
\hline $\begin{array}{l}\text { Low methoxy Amidated } \\
\text { pectin beads }\end{array}$ & $\begin{array}{l}\text { Indomethacin, } \\
\text { Sulphamethoxazole }\end{array}$ & $\begin{array}{l}\text { Beads are prepared from single droplets produced by } \\
\text { pumping drug formulations through diameter tube at } \\
1.6 \mathrm{~mm} / \mathrm{min} \text { using a peristaltic pump }\end{array}$ & 46 \\
\hline Calcium pectinate beads & Resveratrol & Ionotropic gelation Method & 47 \\
\hline $\begin{array}{l}\text { Calcium pectinate } \\
\text { microbeads }\end{array}$ & Satranidazole & lonotropic gelation method & 48 \\
\hline $\begin{array}{c}\text { Calcium pectinate gel } \\
\text { beads }\end{array}$ & prednisolone & Ionotropic gelation method & 49 \\
\hline Pectin bora rice beads & Glipizide & lonotropic gelation technique & 50 \\
\hline $\begin{array}{l}\text { Cross-linked alginate- } \\
\text { cellulose acetate } \\
\text { Acetopthalate Gel spheres }\end{array}$ & Diclofenac sodium & $\begin{array}{c}\text { Gel spheres are formed by titrating drug-polymer } \\
\text { suspension at } 2 \mathrm{~m} / \mathrm{min} \text { by using } 6 \text {-channel peristaltic } \\
\text { pump. }\end{array}$ & 22 \\
\hline $\begin{array}{l}\text { Calcium pectinate gel } \\
\text { beads }\end{array}$ & Bovine serum albumin & $\begin{array}{l}\text { Beads were prepared by extruding pectin solution into } \\
\text { calcium chloride solution. On drying matrix beads re } \\
\text { produced }\end{array}$ & 51 \\
\hline $\begin{array}{l}\text { Silica-coated calcium } \\
\text { pectinate gel beads }\end{array}$ & Theophylline & $\begin{array}{c}\text { Calcium pectinate beads were prepared by } \\
\text { ionotropic gelation by immersing in a prehydrolysed } \\
\text { tetraethoxysilane solution }\end{array}$ & 52 \\
\hline $\begin{array}{l}\text { Calcium zinc pectinate gel } \\
\text { beads }\end{array}$ & Mango seed of kernel extract & lonotropic gelation method & 53 \\
\hline $\begin{array}{c}\text { Low methoxylated } \\
\text { Amidated pectin beads }\end{array}$ & Benzyl penicillium & Ionotropic gelation method & 54 \\
\hline Calcium pectinate beads & Azathioprine & $\begin{array}{l}\text { Azathioprine pectin dispersion was added to calcium } \\
\text { chloride followed by drying and coating by fluid bed } \\
\text { coater }\end{array}$ & 55 \\
\hline
\end{tabular}

\begin{tabular}{|c|c|c|c|}
\hline \multicolumn{2}{|c|}{$\begin{array}{c}\text { Table 3: Various microsphere-based dosage forms of parent and modified pectin, with the entrapped drugs and } \\
\text { the respective preparation techniques. }\end{array}$} & \multicolumn{2}{c|}{ Preparation Method } \\
\hline Dosage form & Drug model used & Emulsion dehydration technique & 28 \\
\hline Pectin microspheres & Metronidazole, Tetracycline & Microfluidic synthesis & 56 \\
\hline $\begin{array}{c}\text { Low methoxy Amidated pectin } \\
\text { microspheres }\end{array}$ & Vancomycin & Spray dried process & 36 \\
\hline $\begin{array}{c}\text { Pectin microspheres } \\
\text { Pectin-Alginate microspheres }\end{array}$ & Metronidazole & Atomization through nozzle spraying & 28 \\
\hline Pectin microspheres & Capecitabine & Single emulsification technique & 57 \\
\hline $\begin{array}{c}\text { Calcium-Pectinate microspheres } \\
\text { Zinc-Pectin gel microparticles }\end{array}$ & Methotrexate, Sulphanilamide, & External gelation using emulsification & 58 \\
\hline Zinc-pectin microparticles reinforced & Ketoprofen & lonotropic gelation method & 23 \\
\hline with chitosan & Progesterone & Modified ionotropic gelation technique & 59 \\
\hline Pectin microspheres & Prednisolone & Emulsion dehydration technique & 60 \\
\hline
\end{tabular}

\begin{tabular}{|c|c|c|c|}
\multicolumn{5}{|c|}{ Table 4: Various nanoparticle-based dosage forms of parent and modified pectin, with the entrapped drugs and } \\
the respective preparation techniques.
\end{tabular}


tablets have been reported. ${ }^{19}$ Other approaches include use of calcium pectinates, ${ }^{20}$ cellulose derivatives such as HPMC, microcrystalline cellulose and more elaborate techniques such as the formation of zinc pectinate beads followed by compression and use of crosslinking agents to pectins have been reported. ${ }^{21}$

\section{Multi-particulate dosage form}

Due to more predictable gastric emptying time, multiparticulate dosage forms such as beads are preferred. Hydrogel beads are formulated by the dropwise addition of dissolved pectin solution into a solution containing calcium that results in the formation of insoluble calcium pectinate hydrogel beads due to crosslinking between calcium and pectin. ${ }^{22}$ However, researchers used zinc acetate as crosslinker that acts superior to calcium. ${ }^{23}$ These beads can be used as capsule filling or matrix tablet. There are some patents describing the development of beads in which bioactive substance is loaded in the micro-sponge particles and the openings of those particles are sealed with pectins which act as a further coating to beads. ${ }^{21}$

\section{Particulate systems with pectin}

Lee et al. developed micro particles using spray drying technique in which a solution of pectin and drug was spray dried and subsequently crosslinked with calcium. The microparticles produced were in the size range of 3-5 micrometer. ${ }^{24}$ Literature reports on microencapsulation using pectin are scanty. Chavanpatil and Mishra formulated microcapsules with a polyelectrolyte complex by incorporating drug in a mixture containing alginate, ${ }^{25}$ pectin and calcium. ${ }^{26}$ They also reported the preparation of insulin-loaded calcium pectinate nanoparticles by ionotropic gelation method as a promising colonic delivery system and evaluated the influence of pectin molecular weight and formulation $\mathrm{pH}$ on nanoparticles. Eudragit-coated pectin microspheres were also found to be an effective carrier for colon targeted drug delivery. ${ }^{27}$ Pectin microspheres bearing metronidazole coated with Eudragit S100 showed effective treatment for amoebiasis. ${ }^{28}$ Tinidazole formulated using sodium alginate-pectin polysaccharide coated with Eudragit S 100 for the treatment of amoebic colitis have also been reported. ${ }^{29}$

\section{Coating of pectins to confer hydrophobicity}

In order to overcome the hydrophilicity of pectin as well as the low gastric and intestine $\mathrm{pH}$ values, Mura et al. coated matrix pectin tablets with Eudragit S100. ${ }^{18}$ Fell along with his colleagues worked on pectin as a coating material for colon-specific delivery. Later it was observed that pectin was unable to provide efficient protection to the tablets. So, they added film formers like ethyl cellulose, chitosan and HPMC in order to enhance formulation stability. ${ }^{30}$ Pectin-ethyl cellulose mixed film coating system using non aqueous solvent were reported for colon tragetting. ${ }^{31}$ Moreover pectin-gelatin film combination were also reported as protective coating for colon delivery.

\section{Compression coating}

In order to enhance the efficiency of coating, compression coating has been suggested over film coating. The materials reported for compression coating are methoxylated pectin ${ }^{32}$ and calcium pectinate with additives like chitosan, ${ }^{33}$ HPMC and ethyl cellulose. ${ }^{34}$

\section{Pectin in combination with other polysaccharides}

The main challenge lies in avoiding complete dissolution of pectin formulation in vivo until it reaches the colon. Pectin alone is not capable of lasting the 4-6 hrs journey through the upper part of GIT. Hence, formulations of pectin in combination with other polysaccharides or polymers like chitosan, HPMC, Alginates and dextrans have been employed to enhance colon drug delivery. ${ }^{21}$

\section{a) Pectin-HPMC}

Ugurlu et al. reported different combinations of nisin by using pectin/HPMC formulated into compression coated tablets to attain drug release in the colonic region. ${ }^{35}$

\section{b) Pectin-chitosan}

Bigucci et al. reported the improvement of Vancomycin release when designed with pectin-chitosan polysaccharides. Vancomycin was formulated as hydrogel system using pectin-chitosan which limits the drug release in acidic conditions thereby confirming its potential for colonic specific drug delivery. ${ }^{36}$

\section{c) Amidated pectin-chitosan enteric polymers}

Giselle et al. formulated Triamcinolone using chitosan and amidated pectin in combination with Cellulose Acetate Phthalate (CAP) and Hydroxypropyl Methylcellulose Phthalate (HPMCP) polymers that resulted in controlled drug release in the colonic region. ${ }^{37}$

\section{d) Pectin-Eudragit}

Jain et al. reported dicyclomine micro sponges coated with Eudragit S 100 compressed as tablets, which started drug release at the sixth-hour corresponding to arrival time at colon. ${ }^{38}$ 


\section{CONCLUSION}

Pectin being natural polysaccharides has various advantages in food and medicinal applications. This article gives information regarding pectin and its various dosage forms targeting colonic site. Biodegradability, gel-forming nature are the characteristic features of this polysaccharide which drives its selection as carrier for colon specific drug delivery. Being highly hydrophilic, it forms a gel when in contact with the intestinal fluid. However, it has a limitation of early release before reaching target site. This has been addressed by modification of pectin by thiolation, amylation, methylation and crosslinking with cations such as calcium and zinc. Coating pectin with polymers like HPMC, Eudragit or combining with other polysaccharides has also found to be effective in delivery of drug to target site rather than pectin alone. As research and development continue with pectin drug delivery, many other formulations targeting colon are expected to emerge.

\section{ACKNOWLEDGEMENT}

Authors are grateful to Manipal Academy of Higher Education, Manipal for the infrastructure and resources.

\section{CONFLICT OF INTEREST}

Authors declare no conflict of interest.

\section{ABBREVIATIONS}

GIT: Gastro intestinal tract; CAP: Cellulose Acetate Phthalate; HPMCP: Hydroxy Propyl Methyl Cellulose Phthalate.

\section{REFERENCES}

1. Kosaraju SL. Colon targeted delivery systems: Review of polysaccharides for encapsulation and delivery. Critical Reviews in Food Science and Nutrition. 2005;45(4):251-8.

2. Sintov A, Rubinstein A. Colonic drug delivery system. Google Patents. 1996.

3. Sinha V, Kumria R. Colonic drug delivery: Prodrug approach. Pharmaceutical Research. 2001;18(5):557-64.

4. Harholt J, Suttangkakul A, Scheller HV. Biosynthesis of pectin. Plant Physiology. 2010;153(2):384-95.

5. Harholt J, Suttangkakul A, Scheller HV. Biosynthesis of pectin. Plant Physiology. 2010;153(2):384-95.

6. Luppi B, Bigucci F, Abruzzo A, Corace G, Cerchiara T, Zecchi V. Freezedried chitosan/pectin nasal inserts for antipsychotic drug delivery. European Journal of Pharmaceutics and Biopharmaceutics. 2010;75(3):381-7.

7. Sharma R, Ahuja M, Kaur H. Thiolated pectin nanoparticles: Preparation, characterization and ex vivo corneal permeation study. Carbohydrate Polymers. 2012;87(2):1606-10.

8. LeNormand $M$, Mélida $H$, Holmbom B, Michaelsen TE, Inngjerdingen $M$, Bulone $\mathrm{V}$, et al. Hot-water extracts from the inner bark of Norway spruce with immunomodulating activities. Carbohydrate Polymers. 2013;101:699-704.

9. Rascón-Chu A, Martínez-López AL, Carvajal-Millán E, DeLeón-Renova NEP, Márquez-Escalante JA, Romo-Chacón A. Pectin from low quality 'Golden
Delicious' apples: Composition and gelling capability. Food Chemistry. 2009;116(1):101-3.

10. Lara-Espinoza C, Carvajal-Millán E, Balandrán-Quintana R, López-Franco Y, Rascón-Chu A. Pectin and pectin-based composite materials: beyond food texture. Molecules. 2018;23(4):942.

11. Munarin F, Tanzi MC, Petrini P. Advances in biomedical applications of pectin gels. International Journal of Biological Macromolecules. 2012;51(4):681-9.

12. Friend DR. New oral delivery systems for treatment of inflammatory bowel disease. Advanced Drug Delivery Reviews. 2005;57(2):247-65.

13. Maddiboyina B. Ploysaccharide based colon specific nanoparticulate drug delivery system. IJPAR. 2015;4(2):107-5.

14. Xu C, Tan RX, Zhang JS, Mo Y. Calcium pectinate capsules for colon-specific drug delivery. Drug Development and Industrial Pharmacy. 2005;31(2):127-34.

15. Srivastava P, Malviya R. Sources of pectin, extraction and its applications in pharmaceutical industry-An overview. Indian Journal of Natural Products and Resources. 2011;2(1):10-8.

16. Dar MJ, Ali H, Khan A, Khan GM. Polymer-based drug delivery: the quest for local targeting of inflamed intestinal mucosa. Journal of Drug Targeting. 2017;25(7):582-96.

17. Ahrabi SF, Madsen G, Dyrstad K, Sande SA, Graffner C. Development of pectin matrix tablets for colonic delivery of model drug ropivacaine. European Journal of Pharmaceutical Sciences. 2000;10(1):43-52.

18. Mura P, Maestrelli F, Cirri M, Luisa GRM, Rabasco AAM. Development of enteric-coated pectin-based matrix tablets for colonic delivery of theophylline. Journal of Drug Targeting. 2003;11(6):365-71.

19. Ashford M, Fell J, Attwood D, Sharma H, Woodhead P. An evaluation of pectin as a carrier for drug targeting to the colon. Journal of Controlled Release. 1993;26(3):213-20.

20. Rubinstein A, Radai R, Ezran M, Pathak S, Rokem J. In-vitro evaluation of calcium pectinate: A potential colon-specific drug delivery carrier. Pharmaceutical Research. 1993;10(2):258-63.

21. Sande SA. Pectin-based oral drug delivery to the colon. Expert Opinion on Drug Delivery. 2005;2(3):441-50.

22. Pillay V, Danckwerts MP, Fassihi R. A crosslinked calcium-alginate-pectinatecellulose acetophthalate gelisphere system for linear drug release. Drug Delivery. 2002;9(2):77-86.

23. El-Gibaly I. Oral delayed-release system based on Zn-pectinate gel (ZPG) microparticles as an alternative carrier to calcium pectinate beads for colonic drug delivery. International Journal of Pharmaceutics. 2002;232(1-2):199-211.

24. Lee CM, Kim DW, Lee HC, Lee KY. Pectin microspheres for oral colon delivery: Preparation using spray drying method and in vitro release of indomethacin. Biotechnology and Bioprocess Engineering. 2004;9(3):191-5.

25. Chavanpatil M, Mishra B. Studies on pectin as a potential carrier in colonic drug delivery. ACTA Pharmaceutica Sciencia. 2003;45(2).

26. Cheng K, Lim LY. Insulin-loaded calcium pectinate nanoparticles: Effects of pectin molecular weight and formulation $\mathrm{pH}$. Drug Development and Industrial Pharmacy. 2004;30(4):359-67.

27. Paharia A, Yadav AK, Rai G, Jain SK, Pancholi SS, Agrawal GP. Eudragitcoated pectin microspheres of 5-fluorouracil for colon targeting. AAPS Pharmscitech. 2007;8(1):E87-93.

28. Jain A, Khare P, Agrawal RK, Jain SK. Metronidazole loaded pectin microspheres for colon targeting. Journal of Pharmaceutical Sciences. 2009;98(11):4229-36.

29. Zhang L, Sang Y, Feng J, Li Z, Zhao A. Polysaccharide-based micro/ nanocarriers for oral colon-targeted drug delivery. Journal of Drug Targeting. 2016;24(7):579-89.

30. Wakerly Z, Fell J, Attwood D, Parkins D. Studies on drug release from pectin/ethylcellulose film-coated tablets: A potential colonic delivery system. International Journal of Pharmaceutics. 1997;153(2):219-24.

31. Macleod GS, Fell JT, Collett JH. Studies on the physical properties of mixed pectin/ethylcellulose films intended for colonic drug delivery. International Journal of Pharmaceutics. 1997;157(1):53-60.

32. Yassin AEB, Alsarra IA, Alanazi FK, Al-mohizea AM, Al-robayan AA, Al-obeed OA. New targeted-colon delivery system: in vitro and in vivo evaluation using X-ray imaging. Journal of Drug Targeting. 2010;18(1):59-66.

33. Fernandez-Hervas M, Fell J. Pectin/chitosan mixtures as coatings for colon-specific drug delivery: An in vitro evaluation. International Journal of Pharmaceutics. 1998;169(1):115-9. 
34. Turkoglu M, Ugurlu T. In vitro evaluation of pectin-HPMC compression coated 5-aminosalicylic acid tablets for colonic delivery. European Journal of Pharmaceutics and Biopharmaceutics. 2002;53(1):65-73.

35. Ugurlu T, Turkoglu M, Gurer US, Akarsu BG. Colonic delivery of compression coated nisin tablets using pectin/HPMC polymer mixture. European Journal of Pharmaceutics and Biopharmaceutics. 2007;67(1):202-10.

36. Bigucci F, Luppi B, Monaco L, Cerchiara T, Zecchi V. Pectin-based microspheres for colon-specific delivery of vancomycin. Journal of Pharmacy and Pharmacology. 2009;61(1):41-6.

37. Oliveira GF, Ferrari PC, Carvalho LQ, Evangelista RC. Chitosan-pectin multiparticulate systems associated with enteric polymers for colonic drug delivery. Carbohydrate Polymers. 2010;82(3):1004-9.

38. Jain A, Jain SK, Ganesh N, Barve J, Beg AM. Design and development of ligand-appended polysaccharidic nanoparticles for the delivery of oxaliplatin in colorectal cancer. Nanomedicine: Nanotechnology, Biology and Medicine. 2010;6(1):179-90.

39. Momin M, Pundarikakshudu K. Design, development and in vitro evaluation of sennosides tablets containing pectin HPMC for colonic drug delivery. Indian Journal of Pharmaceutical Sciences. 2007;69(3):394.

40. Rubinstein A, Radai R, Ezra M, Pathak S, Rokem JS. In vitro evaluation of calcium pectinate: A potential colon-specific drug delivery carrier. Pharmaceutical Research. 1993;10(2):258-63.

41. Abraham S, Srinath M. Development of modified pulsincap drug delivery system of metronidazole for drug targeting. Indian Journal of Pharmaceutical Sciences. 2007;69(1):24

42. Wu B, Chen Z, Wei X, Sun N, Lu Y, Wu W. Biphasic release of indomethacin from HPMC/pectin/calcium matrix tablet: I. Characterization and mechanistic study. European Journal of Pharmaceutics and Biopharmaceutics. 2007;67(3):707-14.

43. Adkin DA, Kenyon CJ, Lerner EI, Landau I, Strauss E, Caron D, et al. The use of scintigraphy to provide'proof of concept'for novel polysaccharide preparations designed for colonic drug delivery. Pharmaceutical Research. 1997;14(1):103-7.

44. Dangi AA, Divya J. Formulation and evaluation of colon targeted drug delivery system of levetiracetam using pectin as polymeric carrier. Journal of Applied Pharmaceutical Science. 2013;3(1):78.

45. Bigucci F, Luppi B, Cerchiara T, Sorrenti M, Bettinetti G, Rodriguez L, Zecchi V. Chitosan/pectin polyelectrolyte complexes: Selection of suitable preparative conditions for colon-specific delivery of vancomycin. European Journal of Pharmaceutical Sciences. 2008;35(5):435-41.

46. Munjeri O, Collett J, Fell J. Amidated pectin hydrogel beads for colonic drug delivery-an in vitro study. Drug Delivery. 1997;4(3):207-11.

47. Das S, Ng KY. Colon-specific delivery of resveratrol: Optimization of multiparticulate calcium-pectinate carrier. International Journal of Pharmaceutics. 2010;385(1-2):20-8.
48. Tiwari A, Ramteke S, Dahima R, Shukla R. Preparation and characterization of satranidazole loaded calcium pectinate microbeads for colon specific delivery: Application of response surface methodology. Current Nanoscience. 2011;7(4):608-15.

49. Gadalla HH, Soliman GM, Mohammed FA, El-Sayed AM. Development and in vitro/in vivo evaluation of $\mathrm{Zn}$-pectinate microparticles reinforced with chitosan for the colonic delivery of progesterone. Drug delivery. 2016;23(7):2541-54.

50. Ramteke KH, Nath L. Formulation, evaluation and optimization of pectin-bora rice beads for colon targeted drug delivery system. Advanced Pharmaceutical Bulletin. 2014;4(2):167.

51. Sriamornsak $P$. Investigation of pectin as a carrier for oral delivery of proteins using calcium pectinate gel beads. International Journal of Pharmaceutics. 1998;169(2):213-20.

52. Assifaoui A, Bouyer F, Chambin O, Cayot P. Silica-coated calcium pectinate beads for colonic drug delivery. Acta Biomaterialia. 2013;9(4):6218-25.

53. Nithitanakool S, Pithayanukul P, Bourgeois S, Fessi H, Bavovada R. The development, physicochemical characterisation and in vitro drug release studies of pectinate gel beads containing thai mango seed kernel extract. Molecules. 2013;18(6):6504-20.

54. Bourgeois S, Laham A, Besnard M, Andremont A, Fattal E. In vitro and in vivo evaluation of pectin beads for the colon delivery of $\beta$-lactamases. Journal of Drug Targeting. 2005;13(5):277-84.

55. Atara SA, Soniwala M. Formulation and evaluation of pectin-calcium chloride beads of azathioprine for colon targeted drug delivery system. Int J Pharm Pharm Sci. 2018;10:172-7.

56. Kim C, Park KS, Kim J, Jeong SG, Lee CS. Microfluidic synthesis of monodisperse pectin hydrogel microspheres based on in situ gelation and settling collection. Journal of Chemical Technology and Biotechnology. 2017;92(1):201-9.

57. Kumbhar DM, Mali KK, Dias RJ, Havaldar VD, Ghorpade VS, Salunkhe $\mathrm{NH}$. Formulation and development of ethyl cellulose coated pectin based capecitabine loaded microspheres for colorectal cancer. Research Journal of Pharmaceutical Dosage Forms and Technology. 2016;8(4):261-8.

58. Chaurasia M, Chourasia M, Jain NK, Jain A, Soni V, Gupta Y, Jain S. Methotrexate bearing calcium pectinate microspheres: A platform to achieve colon-specific drug release. Current Drug Delivery. 2008;5(3):215-9.

59. Gadalla HH, Soliman GM, Mohammed FA, El-sayed AM. Development and in vitro/in vivo evaluation of $\mathrm{Zn}$-pectinate microparticles reinforced with chitosan for the colonic delivery of progesterone. Drug Delivery. 2016;23(7):2541-54.

60. Dashora A, Jain C. Development and characterization of pectin-prednisolone microspheres for colon targeted delivery. Int J Chem Tech Res. 2009;1(3):751-7.

61. Zimet P, Livney YD. Beta-lactoglobulin and its nanocomplexes with pectin as vehicles for $\omega-3$ polyunsaturated fatty acids. Food Hydrocolloids. 2009;23(4):1120-6.

Cite this article: Muvva A, Chacko IA, Ghate V, Lewis SA. Modified Pectins for Colon-Specific Drug Delivery. Indian $\mathrm{J}$ of Pharmaceutical Education and Research. 2020;54(2s):s12-s18. 